\title{
PUBLIC PARTICIPATION AFTER NATURAL DISASTER - CASE STUDY OF CHRISTCHURCH EARTHQUAKE RESPONSE
}

\begin{abstract}
This paper highlights the interrelated challenges of utilising the concept of public participation ladder in post-disaster planning process. The research was based on the case study of the city of Christchurch in New Zealand, which experienced a tremendous damage after series of earthquakes and aftershocks, that have been occurring since September 2010. Methodology adopted in this paper includes literature review. The true spirit of citizenship which appeared among activists of Christchurch was an expression of their deep relation with the place. The major finding of the paper is that the local, bottom-up initiatives, based on creativity and improvisation may be driving forces of city revival. This paper is raising the importance of delegating power to citizens to find the genius loci, create local identity and a sense of belonging. This symbolic value helps to achieve a resilient city after disaster.
\end{abstract}

Keywords: post-disaster reconstruction, earthquake, strategic planning, public participation, bottom-up initiatives

\section{Streszczenie}

\section{Partycypacja publiczna w obliczu katarstrof naturalnych — studium przypadku reakcji na trzęsienie ziemi w Christchurch}

Coraz więcej obszarów na ziemi zamieszkanych jest przez ludzi, przez co szkody powstałe w wyniku katastrof naturalnych są bardziej dotkliwe. Umiejętność miast radzenia sobie w obliczu katastrof jest kluczowym czynnikiem potrzebnym do zapewnienia bezpieczeństwa oraz wielu innych potrzeb mieszkańców i świadczy o odporności miast (resilience). Niniejszy artykuł bada wyzwania związane z zastosowaniem partycypacji publicznej w procesie odbudowy po katastrofie, wykorzystując przykład Christchurch w Nowej Zelandii. Trzęsienie ziemi, które wydarzyło się we wrześniu 2010 r., było początkiem serii trzęsień ziemi, które nieomal doszczętnie zniszczyły miasto. Od razu po katastrofie rozpoczął się długotrwały proces planowania i odbudowy miasta, który z założenia miał włączyć w niego mieszkańców. W artykule zostały przedstawione działania władzy krajowej i lokalnej oraz oddolne inicjatywy społeczności 
w Christchurch. Do analizy wykorzystano ideę drabiny partycypacji publicznej. Metodologia przyjęta w poniższym artykule obejmuje przegląd literatury. Głównym wnioskiem artykułu jest stwierdzenie, iż lokalne, oddolne inicjatywy, oparte na kreatywności i improwizacji, mogą być siłą napędową odrodzenia miasta. Niniejszy artykuł podkreśla znaczenie przekazywania obywatelom władzy, by dzięki temu budować lokalną tożsamość i poczucie przynależności, oraz odnaleźć genius loci, pomimo utracenia znaczącej części tkanki miejskiej.

Słowa kluczowe: odbudowa po katastrofie, trzęsienie ziemi, planowanie strategiczne, partycypacja publiczna, oddolne inicjatywy

\section{Introduction}

According to International Disaster Database, the amount of natural disasters and human-made catastrophes has grown in recent decades. The extent of destruction and the number of societies affected by it are also bigger due to a rising number of the world population, growing economy, a considerable quantity of areas altered by the humanity, extensive urbanization and infrastructure network.

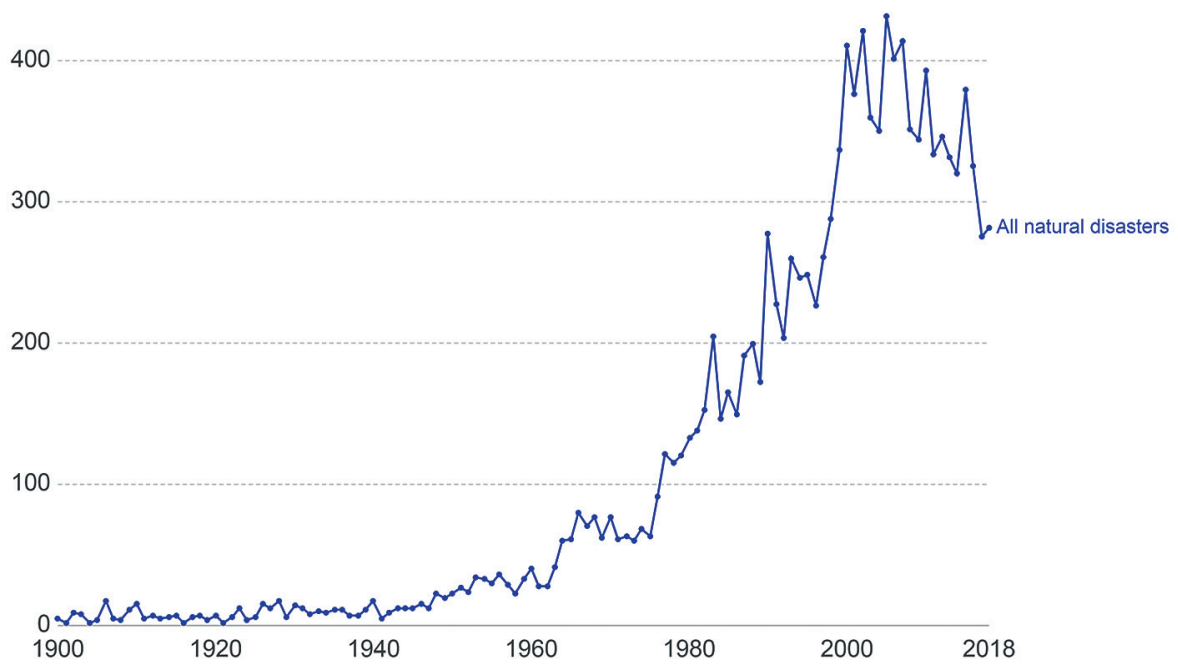

Figure 1. Number of recorded natural disaster events

Source: Ritchie, Roser, 2019.

Urban recovery after catastrophes is a complex problem which requires the contemplation of an important question: How to act quickly but prudentially in case of emergency?

Consideration in this case is not only achieving the status quo by picking up the pieces after a devastating event. It manifests in sensitivity to civic needs and agile 


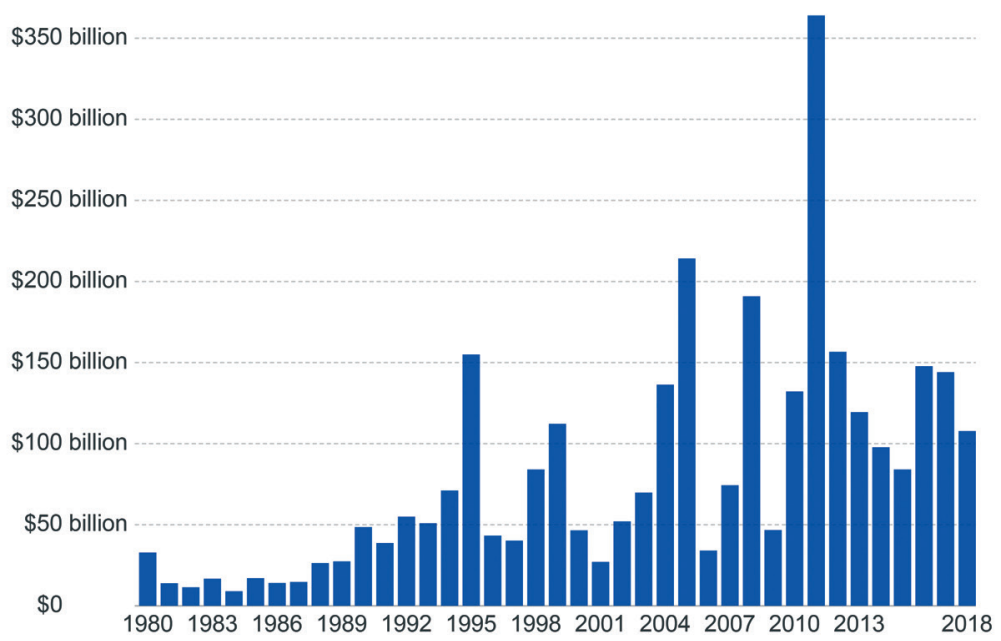

Figure 2. Damage costs from natural disasters

Source: Ritchie, Roser, 2019.

approach to reconstruction as a catalyst to improve the affected area and people's lives. It is both: reconstruction of city systems and creation of new valuable spaces, which are answering to citizen's contemporary and future needs.

Disaster event reaction can be divided into successive stages of action:

a) emergency response - search and rescue operations;

b) restoration - making the built environment safe and understanding the state of land;

c) reconstruction - constructing new buildings and infrastructure, restoring major urban services;

d) improvement - making affected area a better place [Draft Central..., 2011].

Professionalization and centralised, top-down policies dominate in the emergency management discipline. To achieve maximum efficiency during a disaster, response agencies with specialized knowledge are allocated with broad array of power and authority. Efficient response is crucial however, in the long perspective extensive prerogatives may remove emergency managers from the local community, decrease transparency of organisation and lead to accepting incomplete knowledge [Rood, 2012]. Hence, to accomplish comprehensive recovery, all stages of disaster event reaction need to be accompanied by strong partnerships between government agencies, the private sector and civil society [Fernandez, 2011].

In this context community participation can be used to recognize local needs; provide effective early warning systems; to develop or strengthen communitybased disaster risk management programmes and effective preparedness plans [UNISDR, 2005]. Citizen empowerment within disaster recovery offers much more: potentials lay in the fact that local people are the first responders during 
the aftermath of a disaster, they are acquainted to the area and know each other. Moreover, in later stages community and indigenous knowledge can enhance decision-making, help to reach a higher level of well-being and widen the scope of potential solutions by honouring the locality and helping in rebuilding the place around values, which are most important for citizens. Hence, public participation tools should be implemented into all the stages of disaster reaction.

An interesting example of civic engagement in the context of series of earthquakes is the case of Christchurch located in New Zealand, where numerous topdown and bottom-up initiatives were taken by both: authorities and citizens in the scope of recreating a resilient city after devastating events.

\section{The background of Christchurch rebuilding - the Earthquakes}

New Zealand is a country of very high tectonic hazard, but the city of Christchurch has been perceived as the safest part of South Island. It was due to the fact that for the period of 40 years the city experienced 4 earthquakes [GeoNet, 2010] and none of them had widespread consequences. On September 4, 2010, a 7.1 on the Richter magnitude scale earthquake struck. The earthquake epicentre was $40 \mathrm{~km}$ west from Christchurch city centre and depth of $11 \mathrm{~km}$. It was a severe earthquake and caused significant structural damage to residential dwellings but there were no fatalities, mainly because it happened at 4 am when people were still at their homes. This tragic event was a turning point for the city and region of Canterbury. Since then the Earth has continued to shake. From September 2010 to December 2011, 33 shocks over the magnitude of 5.0 occurred and 2,889 shocks over 3.0 on the Richter magnitude scale. On February 22, 2011, a magnitude 6.3 earthquake struck. The ground shook far beyond what the city's building codes had been prepared for because of the earthquake's location: its shallow depth and the area's soil conditions - very high level of groundwater. This time the death toll reached 185 people, thousands were injured and the city's physical infrastructure was devastated. Moreover, in some residential areas of Christchurch liquefaction ${ }^{1}$ overflew roads and homes with enormous amounts of silt and clay. Thereafter, the region of Canterbury experienced a magnitude 6.3 aftershock on June 13, 2011; 6.0 aftershock on December 23, 2011, and 5.9 on February 14, 2016 [4 September Earthquake Fact Sheet, 2012; Christchurch Quake Map, 2012; Pollard, 2013; Livesey, Olivotto, 2015; film: Christchurch Quake].

${ }^{1}$ Soil Liquefaction is a process in which a saturated or partially saturated soil loses strength and stiffness usually in response to earthquake shaking, which is causing it to behave like a liquid. 


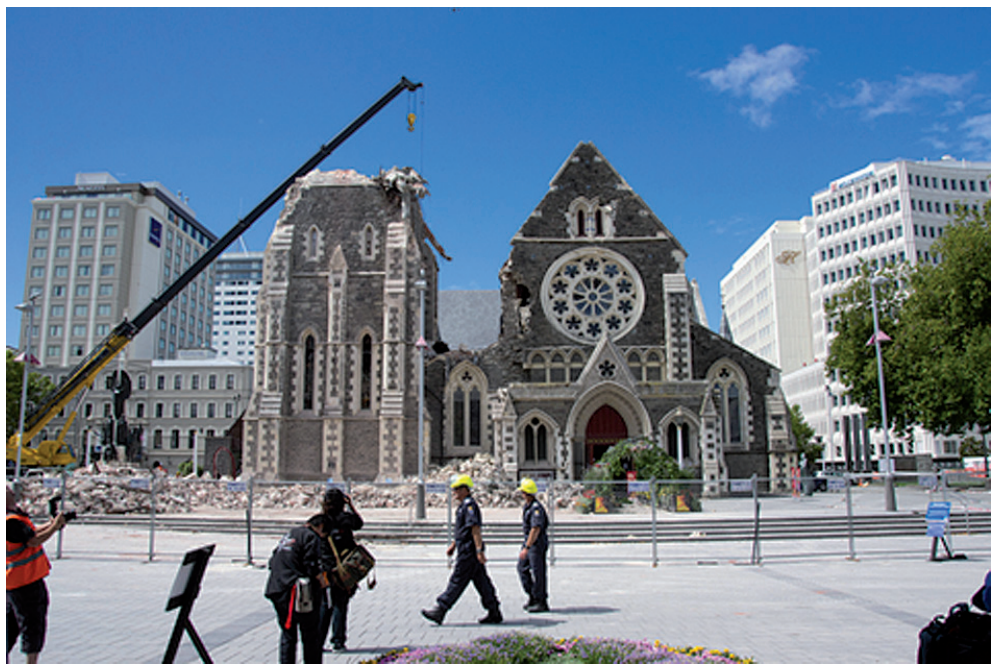

Illustration 1. Christchurch Cathedral after the February 2011 earthquake

Source: https://commons.wikimedia.org/wiki/File:Cathedral_Square_2402.jpg (by Gabriel Goh, https://creativecommons.org/licenses/by/2.0/legalcode).

The earthquakes which struck the city of Christchurch were root to a lot of destruction, disturbance and casualties. The startling amount of earth movements in the region triggered a need for repeated structural assessment of buildings after each moderate and large aftershock. This caused significant prolongation of recovery period. Areas of biggest destruction -387 hectares in the city centre and along the Avon river were fenced and entrance to the area, marked as Red Zone was prohibited. Normal, daily activities in the city centre were stopped or displaced. The level of destruction of Red Zone meant it would need to be completely rebuilt. Christchurch heritage buildings, of which more than half were within the Central City suffered significantly. Many iconic buildings such as Christchurch Cathedral, the Arts Centre or Christchurch Town Hall have been damaged so severely that they needed to be demolished. About 1,200 buildings in the Central Business District (CBD) were pulled down. Likewise, nearly $90 \%$ of residential buildings got damaged and about 7,000 families have been resettled. The city's infrastructure also suffered: $1,628,429$ square meters of roads needed to be repaired or replaced across large parts of Greater Christchurch, $659 \mathrm{~km}$ of sewer pipes and $69 \mathrm{~km}$ of water infrastructure also required recovery. Furthermore, Christchurch experienced an exodus of local business: in years 2011-2012 number of private companies decreased from 5,689 to 3,758 and number of employees from 47,350 to 27,560 [Draft Central..., 2011; February 2011 Christchurch Earthquake, 2011; Colquhoun, 2014].

Abovementioned numbers and facts expose only to some extent the scale of the problem authorities and citizens of Christchurch had to cope with. The city from thriving, lively place in short period of time turned into a ruin. Christchurch 


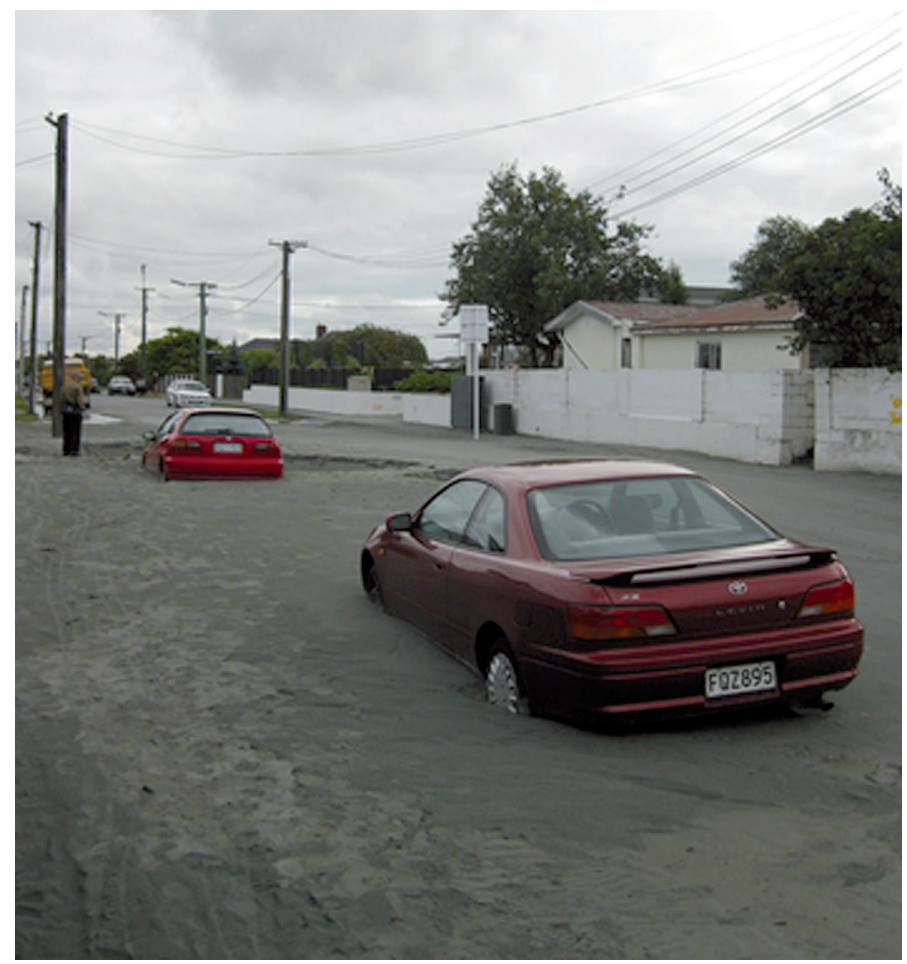

Illustration 2. Liquefaction in Christchurch, causing water and silt to squirt up from underground. St Andrews College, Papanui Road

Source: https://en.wikipedia.org/wiki/2011_Christchurch_earthquake\#/media/File:Christchurch quake_cars,_2011-02-22.jpg (by Timothy Musson, https://creativecommons.org/licenses/by-sa/ 2.0/legalcode).

experienced significant physical damage, lost its retail, social and cultural venues. The loss of heritage buildings has posed a significant challenge to retain links to the past, which is important aspect of local identity. Moreover, it lost many of its citizens because they relocated and among residents who stayed, there was a high level of psychological trauma recorded. The earthquakes have affected everyone and touched all aspects of their life [Christchurch Dilemmas, 2017; films: Christchurch: Resilient City; Christchurch Voices's Videos; The Human Scale].

\section{Reflection on what public participation is}

The point of departure for this paragraph is the concept of public participation discussed in the article written by Sherry Arnstein [1969] A Ladder of Citizen Participation. The author defines the term as follows: 
Citizen participation is a categorical term for citizen power. It is the strategy of redistribution of power that enables the have-not citizens, presently excluded from the political and economic processes, to be deliberately included in the future. It is the strategy by which the have-nots join in determining how information is shared, goals and policies are set, tax resources are allocated, programs are operated, and benefits like contracts and patronage are parcelled out. In short, it is the means by which they can induce significant social reform which enables them to share in the benefits of the affluent society used as a mediating tool for communicating and interpreting needs and priorities of stakeholders, establishing equity, and empowering those without voice [Arnstein, 1969].

To understand the issue better, the author created a scheme called "Ladder of Citizen Participation" (see Figure 3), which became very popular because it systematizes and clarifies the increasing range of public impact in the process of planning.

The eight levels of the ladder are: manipulation, therapy, information, consultation, placation, partnership, delegated power and citizen control. Two first levels are tiered as "non-participation", because they substitute a genuine public participation. The rung number one is manipulation, which may mean misinforming the public to achieve goals by the powerholders. Manipulation also happens when education, persuasion and advising is targeted only at citizens, instead of going reverse. The second rung is the therapy, which aims to cure citizens of their "pathology" rather than involve them in planning. At the stage of informing, the public is provided with information, assisted in understanding the issue and shown alternatives and opportunities. The level of consultation allows to obtain public feedback on analysis. Placation is to work with the public throughout the process but the powerholders retain the right to decide. These three stages are tiered as tokenism because citizens can be heard but there is no guarantee that their views and suggestions would be considered and implemented in the planning, thus the process becomes an "empty ritual." Prevalently, tokenism can be recognized at public consultation workshops and in town hall meetings, where participants may voice their opinions on proposals which were developed earlier. Finally, the direct public participation evinces as:

- partnership, which means to partner with the public in each aspect of the decision including the development of alternatives and the identification of the preferred solution,

- delegated power which allows the citizens major decision-making,

- citizen control happens when final decision-making is placed in the hands of the public.

Ladder of citizen participation attempts to define participation by identifying a hierarchy of levels of public involvement in development processes. Another classification system which helps to characterize participation efforts is the concept of a democracy cube described in the article Varieties of Participation in Complex Governance by Fung [2006]. The author outlines that the democracy cube consists of three dimensions along which forms of citizen participation mechanisms vary: scope, means of communication and decision making, extent of authority and power. The first dimension concerns who participates: it can be open to all 
or addressed to elite stakeholders and interest group representatives. The second determines how participants exchange information and make decisions, and finally, the third dimension specifies the correlation between discussions made and implementing them into public action.

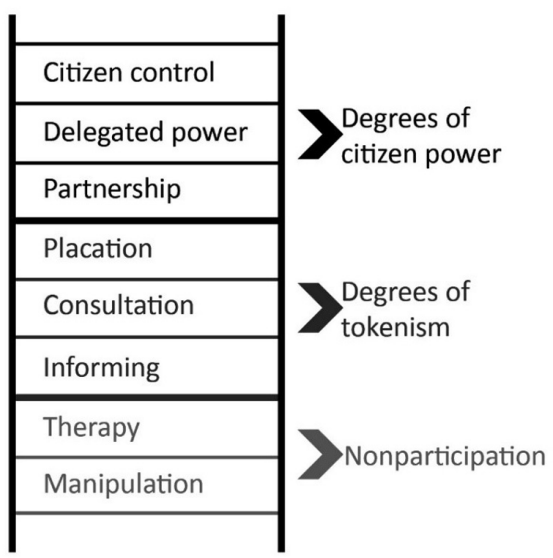

Figure 3. Eight rungs on a ladder of citizen participation

Source: Arnstein, 1969.

Three dimensions of Democracy Cube

\begin{tabular}{|c|c|c|c|c|c|c|}
\hline \multicolumn{3}{|c|}{$\begin{array}{l}\text { Methods of } \\
\text { Participant Selection }\end{array}$} & \multicolumn{2}{|c|}{$\begin{array}{c}\text { Modes of Communication } \\
\text { and Decision }\end{array}$} & \multicolumn{2}{|c|}{$\begin{array}{l}\text { Extent of Authority } \\
\text { and Power }\end{array}$} \\
\hline $\begin{array}{r}\text { More } \\
\text { Exclusive }\end{array}$ & 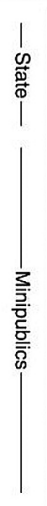 & $\begin{array}{l}\text { Expert } \\
\text { Administrators } \\
\text { Elected } \\
\text { Representatives } \\
\text { Professional } \\
\text { Stakeholders } \\
\text { Lay } \\
\text { Stakeholders } \\
\text { Random } \\
\text { Selection } \\
\text { Open, Targeted } \\
\text { Recruiting } \\
\text { Open, } \\
\text { Self-Selection }\end{array}$ & $\begin{array}{l}\text { Least } \\
\text { Intense }\end{array}$ & $\begin{array}{l}\text { Listen as } \\
\text { Spectator } \\
\text { Express } \\
\text { Preferences } \\
\text { Develop } \\
\text { Preferences } \\
\text { Aggregate and } \\
\text { Bargain } \\
\text { Deliberate and } \\
\text { Negotiate }\end{array}$ & $\begin{array}{r}\text { Least } \\
\text { Authority }\end{array}$ & $\begin{array}{l}\text { Communicative } \\
\text { Influence }\end{array}$ \\
\hline $\begin{array}{l}\text { More } \\
\text { Inclusive }\end{array}$ & $\begin{array}{l}\frac{1}{0} \\
\frac{5}{6} \\
\frac{0}{5}\end{array}$ & $\begin{array}{l}\text { Diffuse } \\
\text { Public Sphere }\end{array}$ & $\begin{array}{l}\text { Most } \\
\text { Intense }\end{array}$ & $\begin{array}{l}\text { Deploy Technique } \\
\text { and Expertise }\end{array}$ & $\begin{array}{l}\text { Most } \\
\text { Authority }\end{array}$ & $\begin{array}{l}\text { Direct } \\
\text { Authority }\end{array}$ \\
\hline
\end{tabular}

Figure 4. Three dimensions of Democracy Cube

Source: Fung, 2006. 
Public participation is a very important aspect of city management and can be used as a mediating tool for communicating and interpreting needs and priorities of stakeholders, establishing social justice. It is also an important component in the process of democratizing the recovery after natural disasters. The abovementioned process does not allow for one size fits all solutions because it depends on context, understanding stakeholder groups, analysis of their needs and priorities. Planning public participation process needs to consider patterns of human behaviour, for instance: when facing the disaster rebuilt and public engagement concerning strategic long-term issues, people's ability to think beyond the immediate response phase of a catastrophe might be compromised by the impact of the disaster [Greater Christchurch Group (GCG), 2017]. Moreover, public participation entails many other variables like distinctive participant choice, deciding upon ways of communication with them, means of decision making and extent of authority. Conducting valuable civic engagement initiatives is also more than maximising public involvement. Delegating power, which according to Arnstein indicates successful civic engagement, may not be suitable to all situations or/and does not always result in high quality planning.

The starting point of every civic participation process is establishing main participants and networks and to ensure they cooperate. Post-disaster reconstruction also requires negotiations among a wide array of interests and expectations, because challenges that emerge cannot be approached by one single recovery actor. In case of the Christchurch earthquake, the entire recovery community was very large and relationships between them were complex. The main groups were: central and local government agencies, Ngāi Tahu ("People of Tahu" - the indigenous Maori people of the southern islands of New Zealand), communities, business community, non-governmental organisations and individuals.

Table 1

Three pillars of Christchurch Earthquake Recovery Process

\begin{tabular}{|c|c|c|c|c|}
\hline $\begin{array}{l}\text { Actors and networks } \\
\text { - Government agencies } \\
\text { - Local councils } \\
\text { - Ngāi Tahu } \\
\text { - Non-governmental } \\
\text { organisations } \\
\text { - Business community } \\
\text { - Communities } \\
\text { - Individuals }\end{array}$ & $\begin{array}{l}\Leftrightarrow \Leftrightarrow \\
\Leftrightarrow \Leftrightarrow \\
\Leftrightarrow \Leftrightarrow\end{array}$ & $\begin{array}{l}\text { Disaster event reaction } \\
\text { - Emergency response } \\
\text { - Restoration } \\
\text { - Reconstruction } \\
\text { - Improvement }\end{array}$ & $\Leftrightarrow$ & $\begin{array}{l}\text { Ladder of citizen participa- } \\
\text { tion: } \\
\text { - Partnership, delegated power } \\
\text { and citizen control (delegated } \\
\text { power) } \\
\text { - Informing, consultation and } \\
\text { placation (tokenism) } \\
\text { - Manipulation and therapy } \\
\text { (non-participation) }\end{array}$ \\
\hline
\end{tabular}

Source: own elaboration.

Table 1 outlines three pillars of Christchurch recovery: successive stages of action which need to be taken, actors involved and rungs of public participation ladder as tools for democratizing the process. To achieve a resilient city after disaster, 
these components need to be interrelated: it is important to involve all stakeholders and implement meaningful public participation at every stage of action.

\section{The local authorities and public participation process}

Local authorities perceived the rebuilding process in a long-term view as a chance to create a city that responds to the needs of both: today's residents and future generations. In the planning stage of the rebuilding process, the Christchurch City Council (CCC) demonstrated creative and open attitude. Instead of persuading the public over their own development visions, they started from listening to residents. They intended to transform the Central City into "city for people" with help of civic participation tools implemented into the planning processes. Within 10 weeks from the February 22, 2011 earthquake, local authorities launched "Share an Idea" public participation campaign. The aim was to give voice to needs and priorities of stakeholders and thereafter interpret them so they can be applied in the city planning documents [film: Share an Idea - Community...].

The City Council used various tools to communicate with the public. First tool used to inform public was a website (shareanidea.org.nz), where residents could share their ideas whenever it was convenient. On the web page, people could express how they wanted to move around the Central City, what public spaces and activities they would like to see in the area, what was the type of businesses they thought were appropriate for the Central City and what was needed to attract people back to the Central City to work and live. The website turned out to be very popular; it generated more than 58,000 visits during the six weeks it operated. Another stage of consultations was an initiative which involved in-person meetings with residents: CCC organised two-day Share an Idea Community Expo, which was held on May 2011. During the expo, people could express their opinions and ideas using post-it notes, by making a video clip, building Central City out of Lego and filling out questionnaires. Additionally, CCC organised 10 public workshops, which were attended by 450 residents and placed drop boxes for ideas at the University of Canterbury and Christchurch Polytechnic.

There was a rich variety of media involved to inform and encourage residents to take part in events, such as: Facebook, Twitter, YouTube, radio, television and advertising on newspapers. The Council also created Share an Idea tabloid, which was distributed to 160,000 households in Christchurch and E-newsletters which were sent weekly to 7,000 people. In the promotional materials, special attention was given to the simplicity of language and clarity of the message. In result, the Christchurch City Council achieved a level of community involvement in the public participation that has never been seen in New Zealand before. Above 10,000 residents attended the Community Expo and a total of 106,000 ideas have been shared in the course of the six-week campaign. A team of Council researchers identified the emerging common themes: residents asked for more greenery, 
bicycle lanes and local commerce development, whereas they didn't want big malls and high-rise buildings.

All collected ideas were classified by researchers into topic summaries and grouped under the five core Central City Plan chapter headings. Share an Idea website and community workshops were used to raise issues requiring further investigation from the public. During the public participation process working with the key stakeholders has also played an important role. CCC have organised more than 100 meetings and workshop-type gatherings with individual organisations, professional institutes and business representatives. The meeting intention was to formulate ideas, identify the main activities and projects to revitalise the Central City. This included the 48-hour Challenge Workshop for 15 international teams, which brought together architects, landscape architects, engineers and planners to provide potential solutions for Avon River corridor. The stakeholders and residents' suggestions were gathered and transformed into a set of rules, which would help to achieve the public goals. The CCC created Draft Christchurch Recovery Plan and continued the process of public participation with headwords "tell us what you think". For 10 days public hearings and discussions were organised. On this basis the city council made suitable amendments and corrections [Theelen, 2012].

The Final Draft Christchurch Recovery Plan by CCC [2011] has been created with residents in mind but in the end, it had to gain both: the public and government approval. It turned out not all elements from the plan have been accepted by the national authorities. Christchurch Recovery Minister Gerry Brownlee deliberated on the plan for five months and accepted the general principles. Under the pressure of loaners, developers and insurance companies the government agencies rejected the spatial framework and mechanisms for achieving it [Bennett, Moore, 2017]. Conflict between local and national authorities has risen after the Central authorities took leadership in the rebuild process and ignored many citizen priorities.

\section{The top-down planning by CERA}

After 2010 and 2011 earthquakes New Zealand's Government lifted the National State of Emergency, to help the local authorities because the scale of destruction exceeded their capacity to cover for reconstruction and manage the rebuild of devastated region. The government enacted the Canterbury Earthquake Response and Recovery Act 2010 (CERR Act) and on April 2011 the Canterbury Earthquake Recovery Act 2011 (CER Act) to assign to the central authorities' statutory power to assist with the earthquake response. The CER Act established the Canterbury Earthquake Recovery Authority (CERA) - centralized agency with responsibility to conduct the recovery strategy. In scope of enabling swift and effective decision process and well-coordinated rebuilding, CERA has been given broad powers to sidestep local and national policies [Brookie, 2012]. 
Within nine months from the CER Act being enacted, the CCC was obliged to draft a Recovery Plan for the Central Business District. However, CERA had the right to veto the plan and replace solutions with their own vision of the rebuilding process and outcome and so, they did. The task of rebuilding central city was transitioned from the local to the national level when in April 2012 Earthquake Recovery Minister Brownlee ordered CERA elaborate a new blueprint plan led by consortium of experts. Despite officially declaring the importance of public participation as integral planning component, CER Act did not require broad civic engagement in planning process; it was limited to outreach meetings, consultations and circulating plans for public feedbacks. CERA appointed 38 members of local community from various cultural, social and economic backgrounds for consultation, but collectively they had limited influence and capacity to represent the views of the entire city [Brookie, 2012]. According to governmental Christchurch Central Recovery Plan, the pillars of Christchurch reconstruction were Precincts and Anchor Projects - including a stadium, convention centre, memorial, public parks and an innovation precinct [Bennett, 2014].

Effective management and collaboration among recovery actors are the key component in coordinating disaster recovery at organizational and project level. CERA by reducing public input into the city rebuilt ignored the importance of civic participation in the planning processes. The government assumed that topdown planning is more agile and effective way to deal with impacts of earthquakes and rebuild of Central Business District. Christchurch Central Recovery Plan was created without true cooperation between governing agencies and local people, which resulted with strong criticism and dissatisfaction among citizens. As a result, CERA after five years of operating was destabilised and the government, which transitioned the recovery to locally-led institution - Ōtākaro. Ōtākaro continued their work on delivery of Anchor Projects and Precincts outlined in the CCRP [Theelen, 2012; Dann, 2013; Lukey, 2016]

\section{The bottom-up initiatives}

According to social science research described in a study report Facing Hazards and Disasters Understanding Human Dimensions [National Research Council, 2006] public behaviour during earthquakes and other major community emergencies is overwhelmingly adaptive and focused on sustaining the safety of others and community life recovery. Adaptive collective mobilization during disasters may take various forms, ranging from spontaneous and informal efforts to provide assistance to more organized emergent group activity, and finally to more formalized organizational arrangements.

The abovementioned predominance of prosocial behaviour has been witnessed during and after the Christchurch earthquake. From early disaster recovery stages people of Christchurch have been critical component of the emergency response and city's regeneration. According to the NZ Landcare [Fitt, 2011] 
research, 92 community-based activities have been recorded within two months after the second major earthquake. All social groups have been actively engaged in help and mutually supported each other. One example of early response is the University Student Volunteer Army which was created in reaction to extensively slow response from professional services. The group, initiated by a student Sam Johnson, managed to organize more than 2,500 volunteers, who were assisting the residents in need and helped in the clean-up of over 65,000 tonnes of liquefaction in Christchurch residential areas. Students created a structure which was relying on teamwork and division of responsibilities. The Student Volunteer Army was divided into Battalions, Squadrons and Street teams. They used web of social media such as Facebook groups, Twitter, google mapping to mobilize and share information. Using new means of communication proved to be very efficient and much more successful than traditional systems. The activity of the Student Army strengthened communities; it was a proof of citizen's ability to find their own solutions and to be actual partners for professional organisations at the stage of emergency response.

SVA became an organisation mainly focused on making volunteering a part of the student experience. However, they have continued to share their expertise on disaster response, explaining how to prepare and become more resilient to disasters in numerous places around the world. Student Volunteer Army representatives helped in: rebuilding school classrooms in remote Himalayan villages after

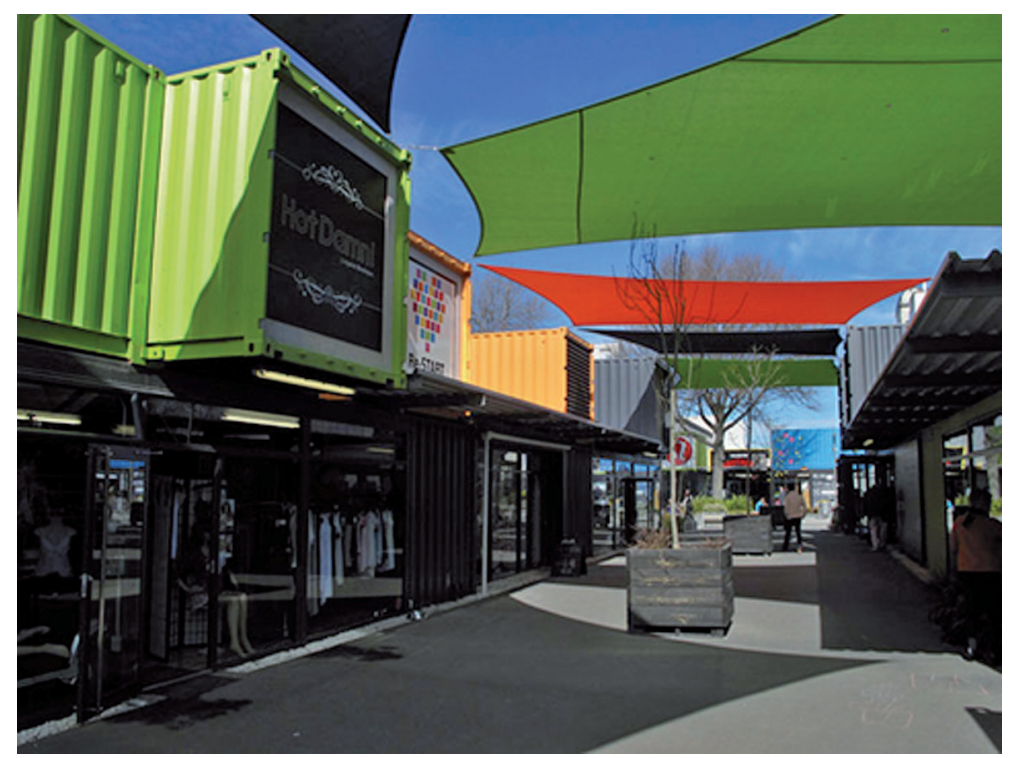

Illustration 3. Places to eat and meet at Restart Mall in Christchurch

Source: https://www.avatar.co.nz/free-christchurch-photographs/\#img/016.jpg (by Avatar, Christchurch Web Designer). 
Nepal quake [McCarthy, 2015], organizing Japanese university students develop a similar volunteer program after tsunami, and nuclear plant meltdown in Japan [McKenzie, 2011] and provided assistance in recovery efforts after Hurricane Sandy in New York [Student Volunteer Army, 2017a; 2017b].

In October 2011 the city's Property and Owners Group as a result of community based design process opened Re:START Container Mall. This temporary space was created to bring people back to desolated city centre. The initiative turned out to be a great success and became very popular among residents and tourists as an iconic symbol of the city in transition. Containers were home to over 50 business in all fields and it enlivened Central Business District before buildings were erected. The Re:START Container Mall lasted five-and-a-half-years and in that time from creative retail centre it evolved into inspiring symbol of citizen power, when private initiative can positively influence the perception of the whole city [Re:START Mall, 2018].

Another creative citizen-led initiative is SCAPE Public Art organisation, which focuses on installing free to view contemporary public art related to the local context. Their aim is to engage the residents emotionally and create new bounds between people and spaces. As a result of their activity, empty and ruined places of Christchurch became canvasses for visually striking artistic expression. SCAPE initiatives are a stimulus to healing residents from Art in the city space has many positive outcomes; it nourishes imagination, broadens horizons and encourages to think out of the box. It has also proven to be very important element of bottom up initiatives positively shaping the perception of city in transition [SCAPE Public Art Christchurch, 2017].

One of the most distinguished grass root group created in response to Christchurch earthquakes is Gap Filler - urban regeneration initiative which focuses on activating city spaces for temporary, creative, people-centred goals. Their aim is to try new ideas, push social boundaries and adopt participatory processes to involve residents in co-creating their home town and enliven empty spaces. Gap Filler is working with community groups from various backgrounds on a broad spectrum of temporary projects, events and installations. Gap Filler arranges places where people could meet with friends and do something together for example dance on the open-air on "Dance-O-Mat" dancing scene, play mini golf on self-made trail, or go to an open-air cinema, which could be powered by riding a bike. They organised many initiatives, among which was the Pallet Pavilion - temporary public space made of 3,000 pallets. The construction engaged 250 volunteers, who ranged in age from 16 to 65 and received support from over 55 business representatives and local authorities. The Pallet Pavilion offered a wide array of uses: from a concert venue to children's play space, it also served for events of small and mid-size scale. Owing to its multi-faceted functions and originality in short period of time the space attracted 25 thousand people. The activity of Gap Filler can be perceived as demonstration of public needs and preferences. It is also an inspiring example of delegating power to residents, who are taking action to shape their spaces. Such bottom-up initiative brings psychological benefits of healing people from trauma, giving them hope for the future and inspiring to co-create new and better reality. 


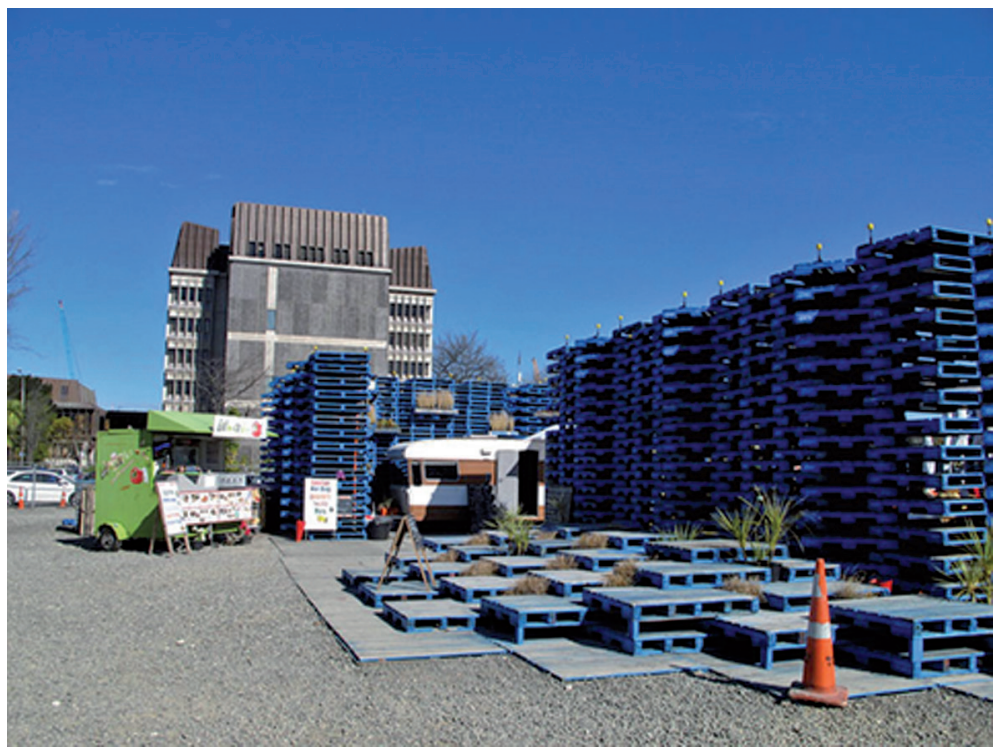

Illustration 4. Food stalls and event spaces at Pallet Pavilion

Source: https://www.avatar.co.nz/free-christchurch-photographs/\#img/019.jpg (by Avatar, Christchurch Web Designer).

The activity of Gap Filler received world renown and became an exemplification of how temporary spaces can bring life to the city and how it affects the long-term rebuilding process [Donovan, 2013; Coralie Winn - Gap Filler, 2017; film: Gap Filler, A Creative Urban Regeneration Initiative].

Gap Filler's close allies were an informal group, which emerged in Christchurch under the name "Greening the Rubble." The general aim of the group was to bring more biodiversity into the city using vacant spaces in the city fabric. To achieve it, they conducted planting and temporary landscaping projects in empty areas. Greening the Rubble was mobilising in its activities hundreds of volunteers, mostly high school and Landscape Architecture students from Lincoln University in co-creating spaces that support connection with nature and wellbeing. As a result, they created temporary public parks and gardens on vacant land.

Gap Filler and Greening the Rubble received support from CCC, which provided funding for part-time workers, who organised projects, their promotion and execution with a help of local people [Montgomery, 2012; 2013; film: Christchurch: The Ever Evolving City].

Earthquakes caused tremendous damage, but at the same time evoked some positive aspects: encouraged people to take action, co-create their city and build communities. Rich variety of collective citizen initiatives demonstrated self-reliant and creative attitude towards problem solving. The temporary spaces became a symbol of an alternative approach to the rebuild: site specific, based on 


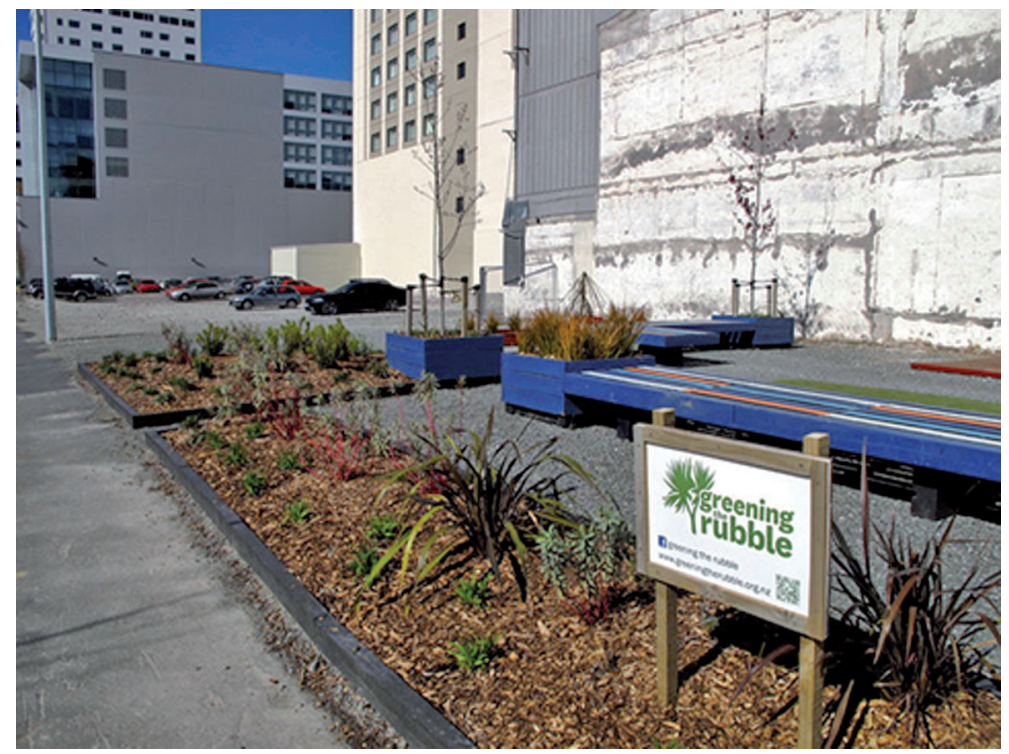

Illustration 5. Temporary greenery in Christchurch empty spaces, as a part of Greening the Rubble initiative

Source: https://www.avatar.co.nz/free-christchurch-photographs/\#img/025.jpg (by Avatar, Christchurch Web Designer).

experiments and adaptability, created with and for local people. Moreover, it is the highest level of public participation, when people actively co-create the city.

While the public was waiting for the finished governmental project, transitional city flourished with unfinished, bottom-up activities. Temporary initiatives focused on context and solutions for improvement of current state with available resources, whereas master plans concentrated on the future and on what the city doesn't have. Transitional city created by the public was to provide decision makers with a "waiting room" before plans created by experts come to reality. In the city of Christchurch, it became apparent that there is a strong division between residents and their creative participation in transitional city and national authorities which led the rebuilding process in "business as usual" convention. Instead of waiting for a revolution created by a group of experts, evolutionary attitude of shifting from temporal to permanent could be of more benefit to the city success and public content about the earthquake rebuilding process [Lesniak, 2016; Simons, 2016]. 


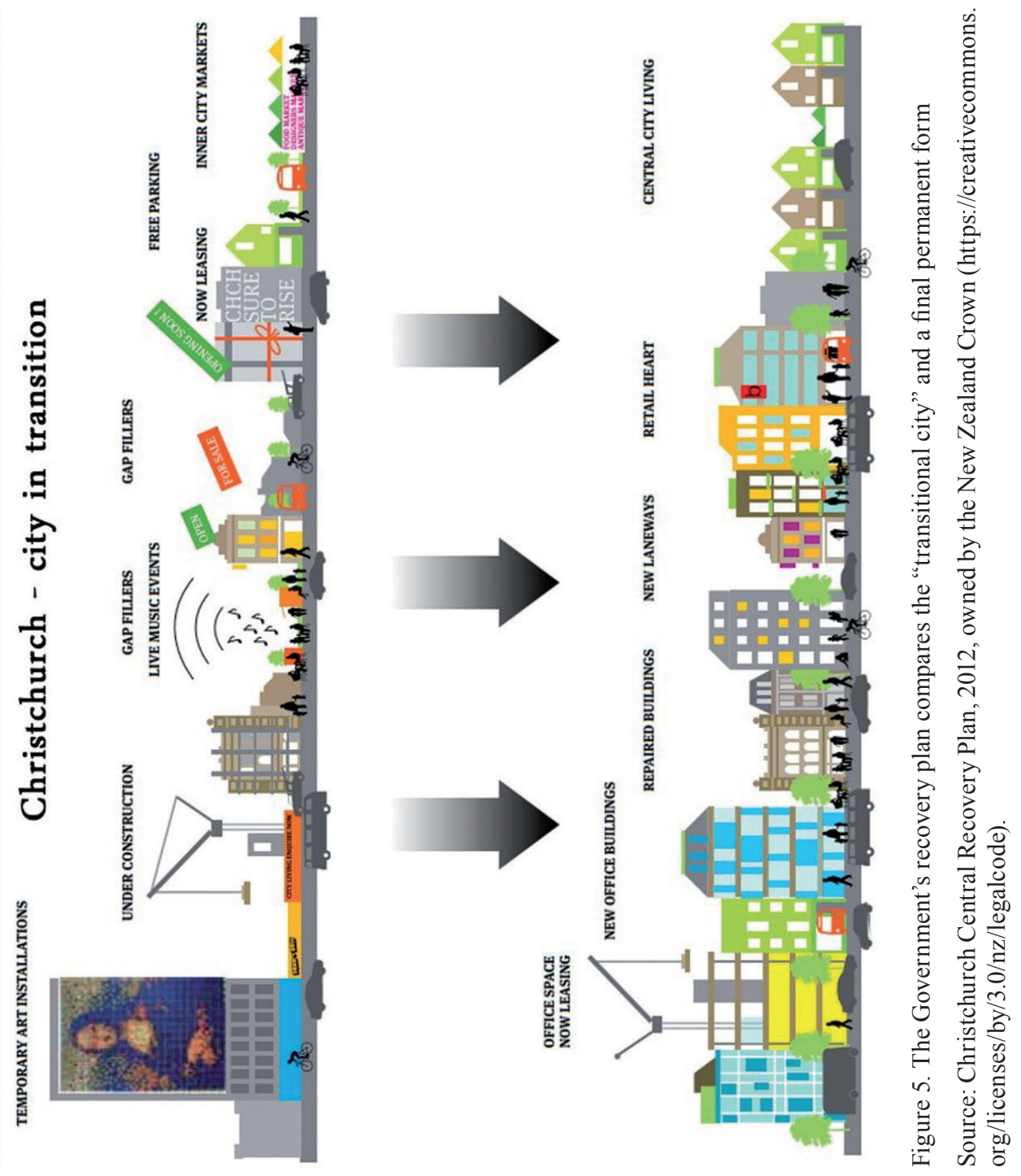




\section{Conclusion}

The rebuilding of Christchurch after a series of earthquakes is a case study of city planning which represents all spectrum of public participation means: from manipulation to degrees of delegated power. One of the aims of Christchurch recovery planning efforts was to balance top-down centralised control and decision-making with statutorily enabled bottom-up community input into decision-making. Such bottom-up initiatives manifested in transitional city with temporary projects created by residents. These can serve as an example of delegated power and partnership rungs of Arnstein public participation ladder. Draft Recovery Plan by Christchurch City Council represents a level of placation. CCC organised public consultation and workshops. Both CCC and to some extent CERA fulfilled the stage of informing the citizens and assisting them in understanding issues related to earthquake recovery. Finally, example of non-participation: CERA blueprint, which was ignoring citizen-led initiatives, residents' ideas and priorities to perform their own development vision.

The attitude towards post-disaster recovery is changing because contemporary cities have to implement democratic decision-making in the rebuilding processes. Valuing and taking advantage of local people resources, capabilities and knowledge changes the role of residents in the rebuild process. People transform from a passive agent that is consulted during design, perceived only as an enduser to a more meaningful role as an active participant, co-creating the ongoing life of buildings and cities.

The case study of Christchurch recovery story is mixed and multi faced: despite the governmental efforts, the activity of CERA continued to represent business as usual approach whereas citizen-led initiatives in post-disaster environment became a success and inspiration to many public interventions around the world. Based on the Christchurch story, it can be noticed the constructive role of community groups. They were able to take the initiative and create innovative forms of leadership when official governance structures had difficulties to provide the necessary services in a post-disaster environment. Studying the Christchurch civic engagement, it becomes evident that the power of people is manifested by their creativity, which can shift into one of the driving forces for city's revival. The true spirit of citizenship is an expression of people's deep relation with the place, thus it is value which should be protected and nurtured the most. The story has also shown that the public participation is not only about democracy or social justice, it is about thoughtful resource expenditure in the city's recovery.

\section{References}

4 September Earthquake Fact Sheet (2012), http://www.rebuildchristchurch.co.nz/blog/2011 [accessed: 28 September 2016]. 
Arnstein S.R. (1969), A Ladder of Citizen Participation, "Journal of the American Institute of Planners", 35 (4).

Bennett B. (2014), Design and Democracy, City-building after Disaster in Christchurch, https://medium.com/@mrbarnabyb/design-and-democracy-339fa4688d70\#.vz814lul4 [accessed: 17 October 2017] [in:] B. Bennett, J. Dann, E. Johnson, R. Reynolds (eds.), Once in a Lifetime: City-building after Disaster in Christchurch, Freerange Press, Christchurch.

Bennett B., Moore T. (2017), The Temporal and the Temporary. Time, Collaboration and Architecture in Post-quake Christchurch, "The Journal of Public Space", 2 (3).

Brookie R. (2012), Governing the Recovery from the Canterbury Earthquakes 2010-11: The Debate over Institutional Design, Working Paper 12/01, Institute for Governance and Policy Studies, Victoria University of Wellington.

Canterbury Earthquake Recovery Act (2011), http:/www.legislation.govt.nz/act/public/2011/0012/latest/whole.html [accessed: 17 September 2016].

Canterbury Earthquake Recovery Authority (2016), http://cera.govt.nz [accessed: 10 September 2016].

Christchurch City Council (2011), Final Draft Central City Recovery Plan, https://www.ccc. govt.nz/the-council/plans-strategies-policies-and-bylaws/plans/central-city-recovery-plan [accessed: 15 October 2017].

Christchurch Dilemmas (2017), http://chchdilemmas.co.nz [accessed: 15 October 2017].

Christchurch Quake Map (2012), http://www.christchurchquakemap.co.nz [accessed: 8 October 2017].

Colquhoun S. (2014), The Rebuilding of Christchurch, http://www.smh.com.au/national/the-rebuilding-of-christchurch-20140221-337m9.html [accessed: 30 September 2017].

Coralie Winn - Gap Filler (2017), https://www.christchurchnz.com/media/our-people/coralie-winn-gap-filler [accessed: 15 October 2017].

Dann J. (2013), Are There Conflicts of Interest Involving the Christchurch Rebuild?, http:// thedailyblog.co.nz/2013/07/01/are-there-conflicts-of-interest-involving-the-christchurch-rebuild [accessed: 10 October 2017].

Donovan J. (2013), Designing to Heal, Csiro Publishing, Collingwood.

Draft Central City Recovery Plan for Ministerial Approval (2011) Vol. 1, Christchurch City Council, https://ccc.govt.nz/assets/Documents/The-Council/Plans-Strategies-Policies-Bylaws/Plans/ central-city/CentralCityPlanTechnicalAppendicesP02-S.pdf [accessed: 15 October 2017].

February 2011 Christchurch Earthquake (2011), Ministry for Culture and Heritage, https://nzhistory.govt.nz/culture/february-2011-christchurch-earthquake [accessed: 18 November 2017].

Fernandez J. (ed.) (2011), Ecuadormethodological Guide for Post-disaster Recovery Planning Processes. Guidelines and Actions For National, Regional and Local Governments, United Nations Development Program (UNDP) - Bureau for Crisis Prevention and Recovery (BCPR), Ecuador.

Fitt H. (2011), Christchurch Earthquake Activity Inventory, Landcare Research, Lincoln, New Zealand.

Fung A. (2006), Varieties of Participation in Complex Governance, "Public Administration Review", 66.

Gap Filler (2017), http://www.gapfiller.org.nz [accessed: 15 October 2017].

Gawith L. (2011), How Communities in Christchurch Have Been Coping with Their Earthquake, "New Zealand Journal of Psychology", 40. 
GeoNet (2010), Darfield Earthquake Damages Canterbury. Earthquake Commission and GNS Science, https://www.geonet.org.nz/earthquake/story/3366146 [accessed: 15 September 2016].

Greater Christchurch Group (GCG) (2017), Whole of Government Report: Lessons from the Canterbury Earthquake Sequence, https:/dpmc.govt.nz/publications/whole-government-report-lessons-canterbury-earthquake-sequence [accessed: 22 October 2017].

Greater Christchurch Partnership (2015) Resilient Greater Christchurch Plan, http://greaterchristchurch.org.nz [accessed: 10 September 2016].

Greening the Rubble, http://greeningtherubble.org.nz [accessed: 30 October 2017].

Hayward B.M. (2010), Rethinking Resilience: Reflections on the Earthquakes in Christchurch, "Ecology and Society", 18 (4).

Ironside L.S. (2012), Rebuilding Christchurch in the Wake of the 2010 \& 2011 Earthquakes - A Surveyor's Perspective, Conference Material: Fig Working Week 2012 Knowing To Manage the Territory, Protect the Environment, Evaluate the Cultural Heritage, https:// www.fig.net/resources/proceedings/fig_proceedings/fig2012/papers/ts071/TS07L_ironside_5786.pdf [accessed: 20 October 2017].

Kaiser A., Holden C., Beavan J., Beetham D., Benites R., Celentano A., Collett D., Cousins J., Cubrinovski M., Dellow G., Denys P., Fielding E., Fry B., Gerstenberger M., Langridge R., Massey C., Motagh M., Pondard N., McVerry G., Ristau J., Stirling M., Thomas J., Uma S.R., Zhao J. (2012), The Mw 6.2 Christchurch Earthquake of February 2011: Preliminary Report, "New Zealand Journal of Geology and Geophysics", 55 (1).

Kwiatkowski J. (2003), Partycypacja społeczna i rozwój społeczny, Agencja Wydawniczo-Reklamowa, Warszawa.

Lee A.J. (2016) Resilience by Design. Advanced Sciences and Technologies for Security Applications, Springer, Cham.

Lesniak M. (2016), Gauging the Impacts of Post-Disaster Arts and Culture Initiatives in Christchurch. A Literature Review, Prepared for Manatū Taonga - Ministry of Culture and Heritage by Life and Vacant Spaces Charitable Trust, https://mch.govt.nz/sites/default/files/Christchurch\%20Literature\%20Review\%20\%20Main \%20document $\% 20$ 2016\%20\%28D-0660925\%29.PDF [accessed: 22 October 2017].

Livesey B., Olivotto V. (2015), The Threat of Water: Relocation in Cali \& Christchurch. The Distance Plan, http://www.academia.edu/22019955/the_threat_of_water_relocation_in_ cali_and_christchurch [accessed: 3 October 2016].

Lukey L. (2016), New Christchurch Rebuild Entities 'Fraught With Potential Power Conflicts', http://www.stuff.co.nz/the-press/business/the-rebuild/78434610/New-Christchurch-rebuild-entities-fraught-with-potential-power-conflicts [accessed: 12 November 2017].

McCarthy J. (2015), Student Volunteer Army Founder Heading to Nepal, https://www. newstalkzb.co.nz/news/national/student-volunteer-army-founder-heading-to-nepal [accessed: 12 Novemer 2016].

McKenzie-McLean J. (2011), Japan to Use Christchurch Volunteer Model, http://www.stuff. co.nz/national/christchurch-earthquake/4986898/Japan-to-use-Christchurch-volunteer-model [accessed: 2 October 2016].

Montgomery R. (2012), Greening the Rubble in Christchurch: Civic Ecological Reclamation Efforts During a Crisis Event, "Lincoln Planning Review”, 3 (2). 
Montgomery R. (2013), Filling the Gaps from the Christchurch Earthquakes 2010-2013: Greening the Rubble and the Mt Pleasant Community Response Plan as Two Local Initiatives [in:] A. Neef, R. Shaw (eds.), Risks and Conflicts: Local Responses to Natural Disasters (pp. 43-78), Emerald Group, Bingley.

National Research Council (2006), Facing Hazards and Disasters: Understanding Human Dimensions, The National Academies Press, Washington, DC.

Pollard S.D. (2013), Shaken City: Two Years after Its Big Quake, Christchurch Is Still Trembling, "Natural History", 121 (3).

Re:START Mall (2018), www.restart.org.nz [accessed: 10 February 2018].

Ritchie H., Roser M. (2019), Natural disasters, OurWorldInData.org, https://ourworldindata. org/natural-disasters [accessed: 30 May 2019].

Rood J.A. (2012), Public Participation in Emergency Management, "Dissertations and Theses Paper", 333.

SCAPE Public Art Christchurch (2017), http://www.scapepublicart.org.nz [accessed: 10 November 2017].

Simons G. (2016), Projecting Failure as Success: Residents' Perspectives of the Christchurch Earthquakes Recovery, "Cogent Social Sciences", 2.

Student Volunteer Army (2017a), https://en.wikipedia.org/wiki/Student_Volunteer_Army [accessed: 30 October 2017].

Student Volunteer Army (2017b), http://sva.org.nz [accessed: 30 October 2017].

Theelen A. (2012), Public Participation in Environmental Management: The Christchurch Rebuild, A Case Study, "Bachelor of Laws Dissertation”, Otago University, http://www. otago.ac.nz/law/research/journals/otago042042.html [accessed: 10 September 2016].

UNISDR (2005), Hyogo Framework for Action 2005-2015: Building the Resilience of Nations and Communities to Disasters, The United Nations Office for Disaster Risk Reduction, Geneva, Switzerland.

\section{Films}

Christchurch Quake, https://www.youtube.com/watch?v=ImcEfiImGHA [accessed: 23 September 2016].

Christchurch Voices's Videos, https://vimeo.com/christchurchvoices/videos [accessed: 18 September 2016].

Christchurch: Resilient City, https://www.youtube.com/watch? $\mathrm{v}=\mathrm{otv} 4 \mathrm{Jwj} r z n I$ [accessed: 22 September 2016].

Christchurch: The Ever Evolving City, https://vimeo.com/104988946 [accessed: 22 September 2016].

Gap Filler, A Creative Urban Regeneration Initiative, https://vimeo.com/76843200 [accessed: 20 September 2016].

Share an Idea - Community Engagement in The Rebuild Of Christchurch's Central City, https://www.youtube.com/watch?v=Y8rhXYAE-ZY [accessed: 20 September 2016].

The Human Scale, documentary 2012, Director: Andreas Dalsgaard. 
